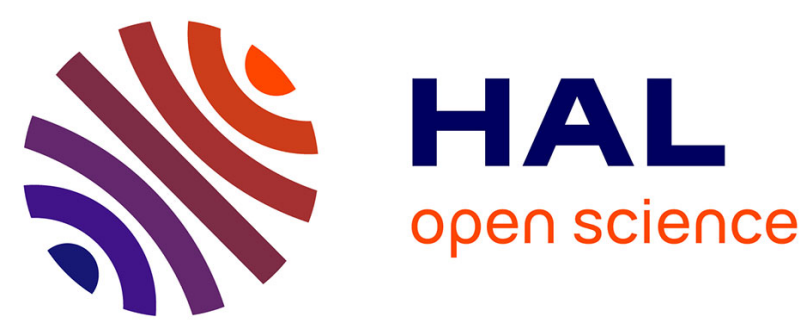

\title{
Unemployment Protection and Family Policy at the Turn of the 21st Century: A Dynamic Approach to Welfare Regime Theory
}

Emanuele Ferragina, Martin Seeleib-Kaiser, Mark Tomlinson

\section{To cite this version:}

Emanuele Ferragina, Martin Seeleib-Kaiser, Mark Tomlinson. Unemployment Protection and Family Policy at the Turn of the 21st Century: A Dynamic Approach to Welfare Regime Theory. Social Policy and Administration, 2013, 47 (7), pp.783-805. 10.1111/j.1467-9515.2012.00855.x . halshs$01318284 \mathrm{v} 2$

\author{
HAL Id: halshs-01318284 \\ https://shs.hal.science/halshs-01318284v2
}

Submitted on 21 Jul 2016

HAL is a multi-disciplinary open access archive for the deposit and dissemination of scientific research documents, whether they are published or not. The documents may come from teaching and research institutions in France or abroad, or from public or private research centers.
L'archive ouverte pluridisciplinaire HAL, est destinée au dépôt et à la diffusion de documents scientifiques de niveau recherche, publiés ou non, émanant des établissements d'enseignement et de recherche français ou étrangers, des laboratoires publics ou privés. 


\title{
Unemployment Protection and Family Policy at the Turn of the 21st Century: A Dynamic Approach to Welfare Regime Theory
}

\author{
Emanuele Ferragina ${ }^{a}$, Martin Seeleib-Kaiser ${ }^{b}$ and Mark Tomlinson ${ }^{c}$ \\ ${ }^{a}$ Researcher, Oxford Institute of Social Policy, University of Oxford \\ ${ }^{\mathrm{b}}$ Professor of Comparative Social Policy and Politics, Oxford Institute of Social Policy, \\ University of Oxford \\ ${ }^{\mathrm{c}}$ Senior Lecturer in Sociology and Social Policy, Department of Sociological Studies, \\ University of Sheffield
}

Ferragina, E., Seeleib-Kaiser, M. and Tomlinson, M. (2013) “Unemployment Protection and Family Policy at the turn of the 21st Century: A Dynamic Approach to Welfare Regime Theory", Social Policy \& Administration, vol. 47 (6), pp. 783-805

\begin{abstract}
This article contributes to the welfare state regime literature from a substantive and methodological perspective. At a very abstract level we confirm the relevance of the welfare state regime theory and stability for the period from 1971 to the end of the 1990s. However, by analyzing family policy and unemployment protection, we observe a dual transformation of the welfare state, consisting of a trend towards a 'socialization' of family policies and a retrenchment in unemployment insurance benefits.

Our Multiple Correspondence Analysis (MCA) of the two policy domains captures the multidimensionality of the decommodification and defamilialization concepts and visualizes welfare state developments over time in a Cartesian space. This dynamic analysis provides us with a nuanced understanding of welfare state regime stability and change.
\end{abstract}

\section{Keywords}

Unemployment protection - Family policy - Decommodification - Socialisation - Multiple Correspondence Analysis 


\section{Introduction}

Over the past two decades comparative welfare state analyses have been strongly influenced by Esping-Andersen's seminal work The Three Worlds of Welfare Capitalism. Many scholars within the field of comparative social policy research have used his regime typology as a heuristic device to analyze and compare different systems and policy domains; others have questioned the appropriateness of the typology (for comprehensive reviews of the literature, see Art and Gelissen 2002, 2010; Arcanjo 2006; Powell and Barrientos 2011; Ferragina and Seeleib-Kaiser 2011). The debate about the appropriateness of Esping-Andersen's regime typology can be interpreted as a symptom for the 'adolescence' (Weber 1904 [1949]: 104) of comparative social policy research, as scholars have not yet learned 'to navigate safely in the vast area of empirical facts' (Weber 1904 [1949]: 104) without using Esping-Andersen's ideal typical construction. While Powell and Barrientos (2011) have suggested that additional research is required at the theoretical level, Ferragina and Seeleib-Kaiser (2011) maintain that more substantive, empirical and methodological work is needed.

Welfare regime typologies have been empirically tested in a rather static manner, by either providing a snap-shot analysis at a certain point in time or by analyzing a limited number of data points (i.e. one by Esping-Andersen [1990] and Shalev [1996, 2007], two by Scruggs and Allan [2006, 2008], and three by Castles and Obinger [2008]), without systematically employing a dynamic temporal analysis over several decades. It is widely accepted within the literature that political parties and power resources have at least historically mattered for the development of the various kinds of welfare regimes, as they relate to the main political movements of Western Europe, i.e. Social Democracy, Christian Democracy and Liberalism (Esping-Andersen 1990; Korpi 1983; Stephens 1979). If, however, political parties have undergone significant transformations over the past decades, as some research would suggest (cf. Pontusson 1995; Rueda 2007; Seeleib-Kaiser 2002; Seeleib-Kaiser et al. 2008), we might expect a substantial transformation of welfare regimes over time. Kittel and Obinger (2003) as well as Huber and Stephens (2001) have identified a declining importance of partisanship in explaining welfare state outcomes. Furthermore, Jessop (1993), for example identifies a major transformation towards a Schumpeterian workfare state, while others, such as Pierson (1994), highlight welfare state resilience and stability, mainly due to the stickiness of institutions and path dependence. Taylor-Gooby (2002) has pointed out that welfare state changes tend to be less visible when using quantitative methods, compared to nuanced qualitative comparisons of policy processes.

This article contributes to the comparative welfare state literature in three ways:

- we propose a dynamic temporal approach to welfare regime analysis;

- we integrate the work-welfare and care-welfare nexi into our dynamic temporal approach;

- we use a quantitative technique known as Multiple Correspondence Analysis (MCA) in order to capture the multi-dimensionality and complexity of change. This method has been selected because it facilitates a superior treatment of categorical variables (for example, 'spiky' distributions, which in other analyses have often been considered as continuous) and places countries into a 'space' allowing for a complex multi-dimensional analysis. 
In order to measure regime stability and change we developed four models. In our first model we use the decommodification potential of unemployment insurance, pension and sickness benefits, as developed by Esping-Andersen, for the period from 1971 to 1999. Although the work-welfare nexus still constitutes a core element of welfare state regimes, it is insufficient to capture very important societal and social policy developments. As already emphasized by Lewis (1992) two decades ago, the care-welfare nexus constitutes a core element of welfare state arrangements and needs to be considered in any welfare regime analysis. Demographic and socio-economic trends as well as the difficulties experienced by parents to reconcile work and care - often subsumed under the heading of new social risks - have further drawn the attention of welfare state scholars and policymakers to the importance of this nexus (Bonoli 2005, 2007; Taylor-Gooby 2004; Mahon 2006). Moreover, many authors have argued that the future of welfare state systems will largely be dependent on improved arrangements to balance work and family life (Crompton 2006; Lewis 1993; Gilbert 2008; EspingAndersen 2009). Hence, our second model focuses on the development of unemployment insurance and family policies for the time period from 1980 to 2008, constituting the first regime analysis to systematically scrutinize the development of the two policy domains in a dynamic analysis. ${ }^{1}$ Unfortunately, we were not able to extend our analysis to the 1970s, as comparable spending data for childcare services are not available. Models 3 and 4 analyze family policy and unemployment protection separately.

Our article is structured as follows: the next section provides a brief review of the main elements of the welfare regime debate from substantive and methodological perspectives; then we present our methodological approach; and the last section discusses the findings of the empirical models and their implications.

\section{Worlds of Welfare: Substance and Methodology}

Esping-Andersen (1990) identified three welfare state regimes, based on the notion of ideal types, which are said to be closely associated with the dominant political movements of Western Europe, i.e. Social Democracy, Christian Democracy and Liberalism. The ideal Social-Democratic welfare state is based on the principles of universalism and social citizenship, and the ideal Christian-Democratic welfare states are based on the principle of subsidiarity and the dominance of social insurance schemes. The Liberal regime is rooted in market dominance and private social provision; the state primarily interferes to alleviate poverty and provides for basic needs, largely on a means-tested basis. Esping-Andersen's work has been discussed and criticized from theoretical (Powell and Barrientos 2011), substantive and methodological perspectives (for a review, see Ferragina and Seeleib-Kaiser 2011). In the following we focus only on substantive and methodological concerns relating to Esping-Andersen's theoretical framework and the concepts of decommodification and defamilialization.

At the substantive level scholarly debates mainly developed around the following three issues:

1. the identification of additional regimes (e.g. Castles and Mitchell [1992] identified a fourth regime, the Radical type, based on a reversed means-testing logic, largely excluding the upper-middle and upper classes from social provisions; Leibfried [1992] and Ferrera [1993,

\footnotetext{
${ }^{1}$ In a recent book Wendt et al. (2011) have analysed typologies with a focus on public opinion.
} 
1996] argued that Mediterranean countries constitute a separate welfare regime cluster, characterized by limited social insurance coverage, clientelism and familialism; Jones [1993] and Goodman and Peng [1996] argued that East-Asian welfare states also form a cluster of their own [see also Esping-Andersen (1997), Kwon $(1997,2005)$ Lee and Ku (2007)]);

2. the (mis)-classification of specific countries (Scruggs and Allan 2006, Bambra 2006); and

3. the application of regime theory to other policy areas such as family policy, education and healthcare (Lewis 1992; Bambra 2004, 2005, 2007; Busemeyer and Nikolai 2010; Wendt 2009; Reibling 2010).

As mentioned in the introduction, none of these studies has either provided a dynamic temporal analysis of the evolution of welfare regimes over time, or a systematic integration of the workwelfare and the care-welfare nexi. Moreover, much of the debate was limited to the discussion about the external validity of Esping-Andersen's regime theory, i.e. the theory was not necessarily applicable in regions or policy areas that he had not included in his initial analysis.

At the methodological level previous analyses have employed descriptive statistics, cluster analysis and principal component analysis to test the regime classification of countries. Descriptive statistics have been employed in two ways, either replicating Esping-Andersen's decommodification index (Bambra 2004; Gal 2004; Bambra 2005, 2006; Scruggs and Allan 2006) or classifying countries according to a two-dimensional double entry table (Castles and Mitchell 1992; Bonoli 1997; Korpi and Palme 1998; Gallie and Paugam 2000; Goodin 2001). As suggested by Bambra (2006) and Scruggs and Allan (2006), these models have three main technical limitations:

1. the increase of measurement errors due to the additive nature of the indices;

2. the creation in every case of a threefold/fourfold typology; and

3. the lack of consistency in the determination of the cut-off points used to classify countries.

In order to avoid the imposition of arbitrary cut-off points, cluster analysis has been used to replace descriptive statistics. Cluster analysis is a family of various algorithms, which group cases on the basis of a range of variables including the most similar cases into the same cluster. Three types of cluster analysis have been proposed within the welfare regime literature:

1. hierarchical cluster analysis (HCA), which finds the closest pairs of cases and then by amalgamation combines other cases to form clusters;

2. k-means cluster analysis (KCA), which proceeds to the amalgamation of cases by starting from a fixed number of regimes determined by the researcher; and

3. HCA and KCA combined simultaneously.

The widespread use of HCA (Kangas 1994; Obinger and Wagschal 1998, 2001; Kautto 2002; SaintArnaud and Bernard 2003; Powell and Barrientos 2004) has been criticised (Gough 2001) for its inductive approach, in that it does not $a$ priori take into account the theoretical framework proposed by Esping-Andersen (Gough 2001). To overcome this problem, Gough (2001) has suggested using KCA, while Castles and Obinger (2008) suggest the integration of HCA and KCA. Despite these methodological innovations in comparative welfare state analyses, these methods cannot fully overcome the shortcomings manifest in descriptive statistics, i.e. there are standardization issues, 
the analysis is unstable (using different algorithms produce different results), and the models are static (Shalev 1996, 2007).

Hence, it has been proposed that Principal Component Analysis ${ }^{2}$ (PCA) may be a more suitable technique to explore welfare typologies (Shalev 1996, 2007; Wildeboer Shut et al. 2001; Soede et al. 2004; Vrooman 2009; Schröder 2009). This is because PCA is:

1. parsimonious (reducing a large number of indicators/policy domains into two or more dimensions); and

2. able to place welfare state regimes into a continuous space. PCA allows researchers to identify hybrid cases and determine which indicators contribute most significantly to the different positions of regimes within the space.

However, the variables used in the welfare state literature are often non-normally distributed and PCA is not well suited for the analysis of such data (Jollife 2002). For example, the distribution of waiting periods in unemployment insurance programmes is extremely spiky and skewed (see figure A1*). Considering such distributions PCA models are not necessarily well suited for analyzing large parts of the data used in the welfare regime literature. In order to deal with this problem we employ MCA, which possesses similar advantages as PCA over other statistical procedures, but in addition more readily allows the recoding of spiky continuous variables into more uniform categories for analysis.

\section{Method and Data}

Multiple Correspondence Analysis and welfare regimes

MCA was pioneered by Bourdieu (1979) to map different types of individual consumption preferences onto a continuous space without resorting to predictive techniques (Le Roux and Rouanet 2010). It is a method that simultaneously associates variables (in our case the categorical variables that define decommodification and defamilialization) and cases (the 18 countries of the Organisation for Economic Co-operation and Development [OECD] included in this study). Hence, if countries within a dataset have particular characteristics represented by categorical variables $A, B$ and $C$ coded into low, medium and high, then the corresponding categories within $A, B$ and $C$ can be plotted onto a two-dimensional space (see figure 1).

\footnotetext{
${ }^{2}$ Other interesting attempts to classify welfare regimes in a multidimensional space have proposed using fuzzy-set technique (Kvist 2007; Vis 2007; Hudson and Kühner 2009, 2012).

* For figures A1-A5, please refer to Appendix.
} 
Figure 1

Multiple Correspondence Analysis - a simplified example

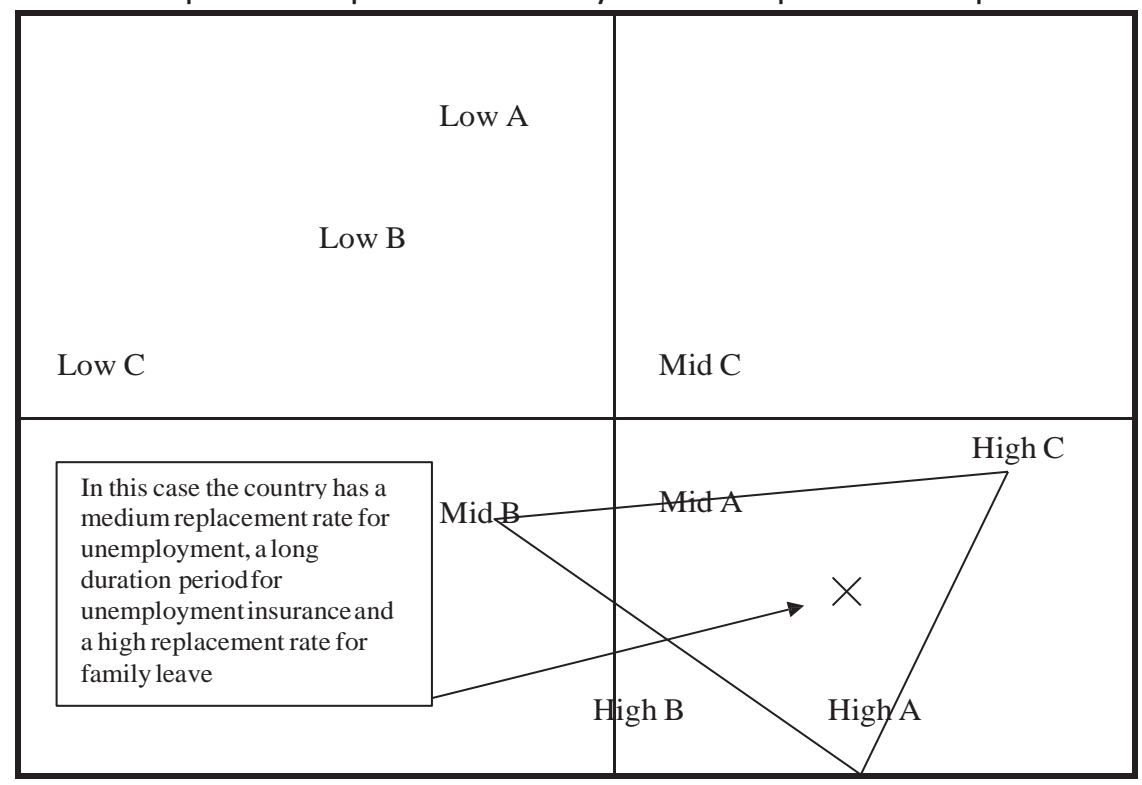

Source: Authors' elaboration.

Notes: A = Replacement rate unemployment. B = Duration period unemployment. $\mathrm{C}=$ Average replacement rate maternity, parental and childcare leave.

Countries and categories are said to occupy a joint space, thus it is possible to interpret the 'category plot' (see figures $\mathrm{A} 2, \mathrm{~A} 3, \mathrm{~A} 4$ and $\mathrm{A} 5^{*}$ ) and then position each country onto the same space (see figures 2, 3, 4, 5, 6 and 7). For example, assume a dataset has three categorical variables: $A$ (the replacement rate of unemployment insurance), B (the duration of unemployment insurance) and $\mathrm{C}$ (the replacement rate of parental leave) and all are coded 'low', 'medium' or 'high' (the categories for each variable). MCA jointly considers countries and categorical variables in the space. Now, suppose that a country within the data scores as follows: High A, Middle B, and High C. This means the country displays a 'high' replacement rate for unemployment and parental leave and a 'medium' duration of the unemployment insurance. By triangulation the country can be placed within the category plot as shown in the figure. Furthermore, by using longitudinal data we are also able to plot countries over time as the categorical variables shift temporally. Finally, a measure of how well the data fit the model is given by the percentage of variance explained. Because the method is not probabilistic there is no requirement for a large dataset or a random sample (Le Roux and Rouanet 2010). 
Figure 2

Multiple Correspondence Analysis decommodification 1971-1999 (Model 1)

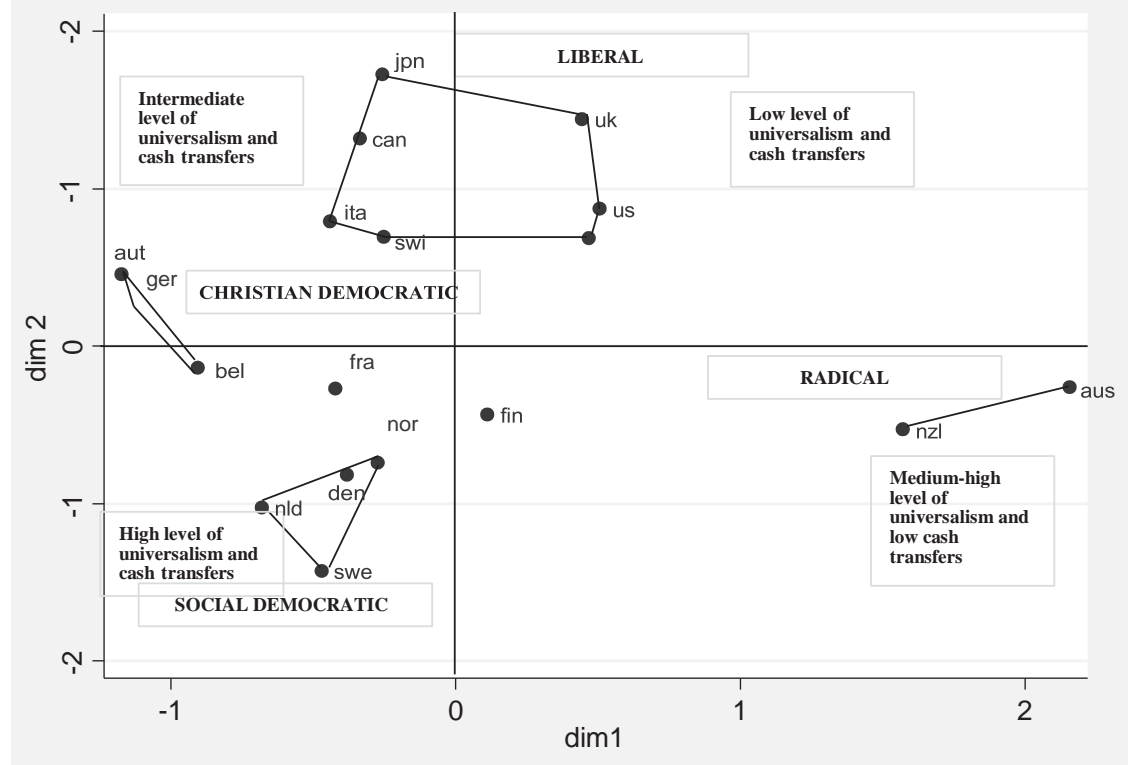

Source: Authors' elaboration.

Note: Aut: Austria; Ger: Germany; Bel: Belgium; Fra: France; Nor: Norway; Den: Denmark;

Nld: the Netherlands; Swe: Sweden; Fin: Finland; Nzl: New Zealand; Aus: Australia; Ire: Ireland; Us: USA; Uk: UK; Jpn: Japan; Can: Canada; Ita: Italy; Swi: Switzerland.

Figure 3

Multiple Correspondence Analysis decommodification over three decades, 1970s, 1980s and 1990s (Model 1)

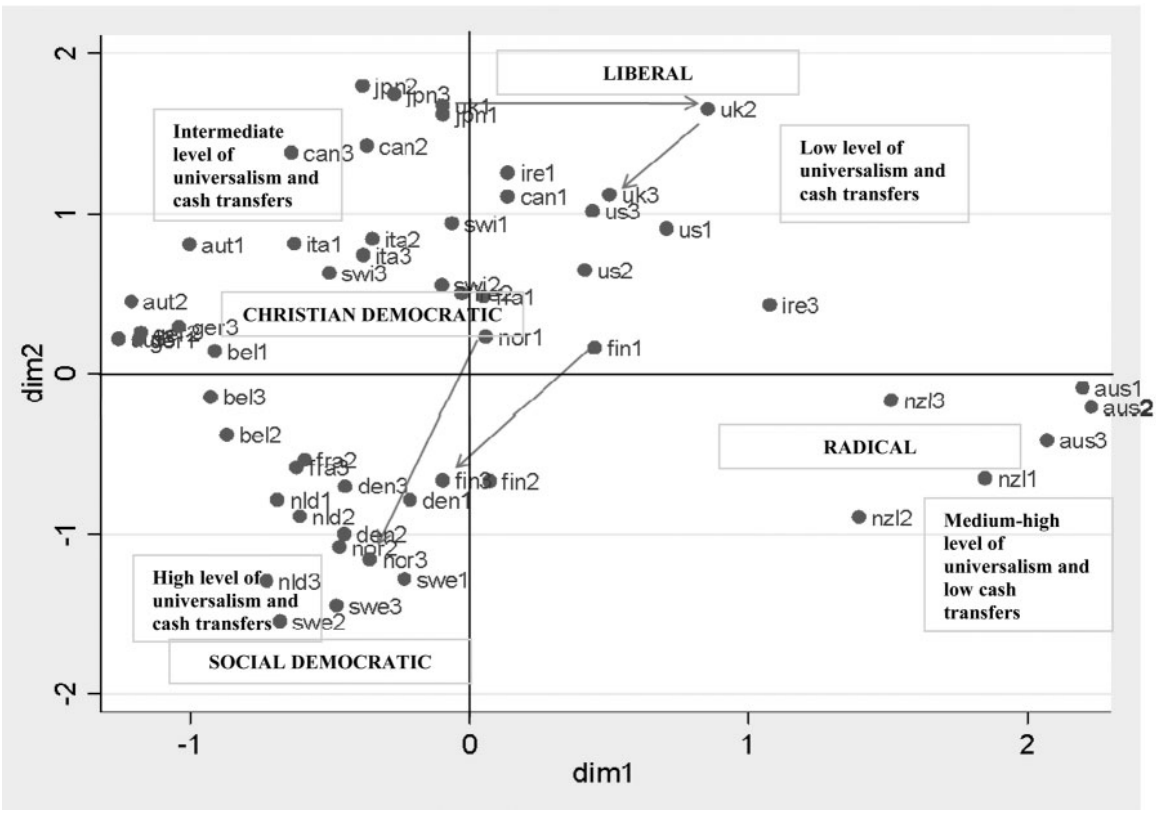

Source: Authors' elaboration.

Notes: Finland 1 represents the position of Finland in the 1970s, Finland 2 in the 1980s and

Finland 3 in the 1990s and so forth for the other countries. For country abbreviations, see figure 2. 
On this methodological basis, we adapted MCA (Bourdieu 1979) to welfare regime theory and our research questions in three steps:

1. We recoded all continuous, count and ordinal variables into quartiles before estimating the model in order to avoid the problems associated with poorly distributed variables.

2. We interpreted the Cartesian spaces emerging from the cloud of indicators and the position of each country in accordance to welfare regime theory (see figures $A 2, A 3, A 4$ and $A 5^{*}$ ), rather than the axes.

3. Lastly, we plotted average scores for different time periods and the 18 OECD countries included in our analysis, allowing us to identify country and regime dynamics across time and space (according to the decommodification and defamilialization concepts). In this way, the trajectory of each country is easy to interpret because the characteristics of the spaces identified by the category plot remain the same over time.

Figure 4

Multiple Correspondence Analysis unemployment protection and family policy 1980-2008 (Model 2)

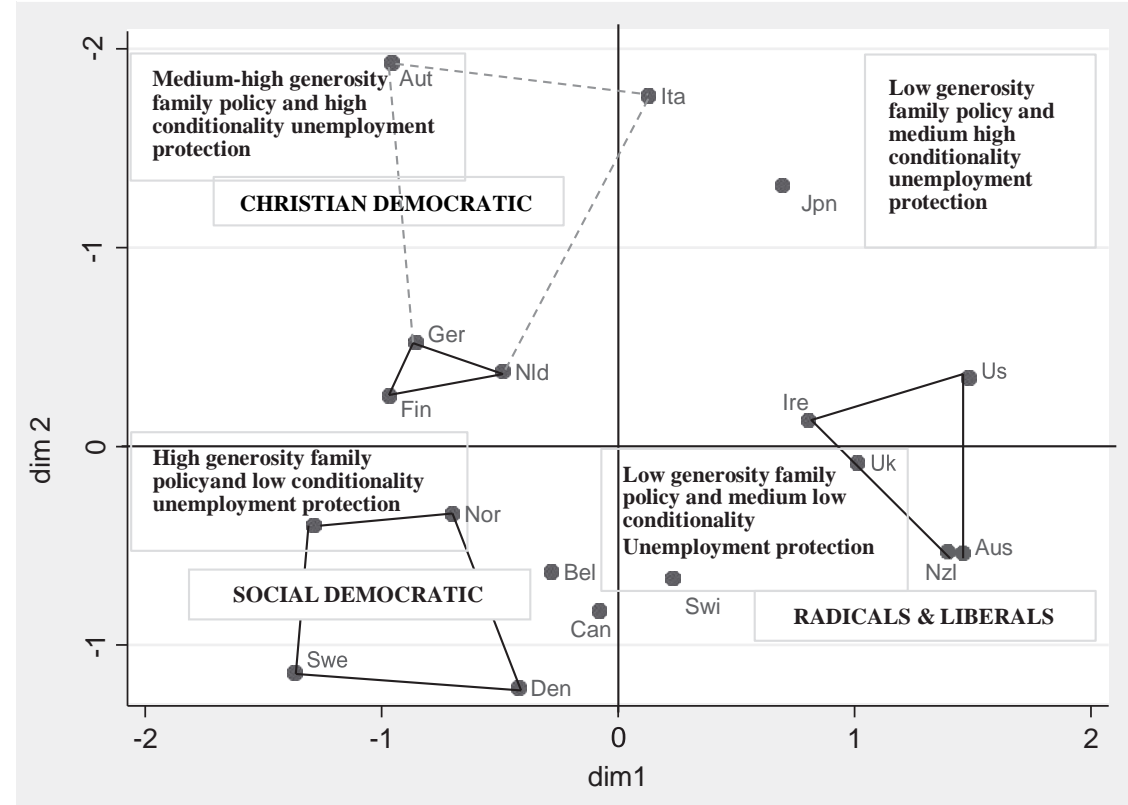

Source: Authors' elaboration.

Note: Finland 2 represents the position of Finland in the 1980s, Finland 3 in the 1990s and

Finland 4 in the 2000s and so forth for the other countries.

For country abbreviations, see figure 2 .

Although not ideal, our temporal analysis is based on averages for various decades, as these were said to be characterized by different dynamics: the 1970s saw the end of the trente glorieuses of welfare state expansion; the 1980s were largely characterized by fiscal consolidation and limited retrenchment, whereas we are increasingly witnesses of processes of adaptation and recalibration since the 1990s (cf. Pierson 2001). Furthermore, our periodization into decades follows Sabatier's argument (1988), whereby it is necessary to consider a minimum period of ten years in order to be able to identify significant policy shifts. ${ }^{3}$ This methodological approach constitutes an improvement

\footnotetext{
${ }^{3}$ We have also tried different periodisations, including five-year periods; however, the differences
} 
compared to the previous literature, which has either employed a very static analysis or focused on few data points (see the second section).

\section{The indicators}

Following Esping-Andersen (1990, 1999) we employ the concepts of decommodification and defamilialization (Esping-Andersen 1990, 1999) ${ }^{4}$. 'Decommodification refers to the degree to which individuals, or families can uphold a socially acceptable standard of living independently of market participation' (Esping-Andersen 1990: 47). The decommodification potential of a country is determined by the sum of the scores for universalism and the generosity (based on eligibility rules and replacements rates) of social protection programmes in the domains of 'old' social risks, covering unemployment, sickness and old age (Esping-Andersen 1990: 47; for a list of the indicators used for each model, see table 1).

Figure 5

Multiple Correspondence Analysis unemployment protection and family policy over three decades, 1980s, 1990s and 2000s (Model 2)

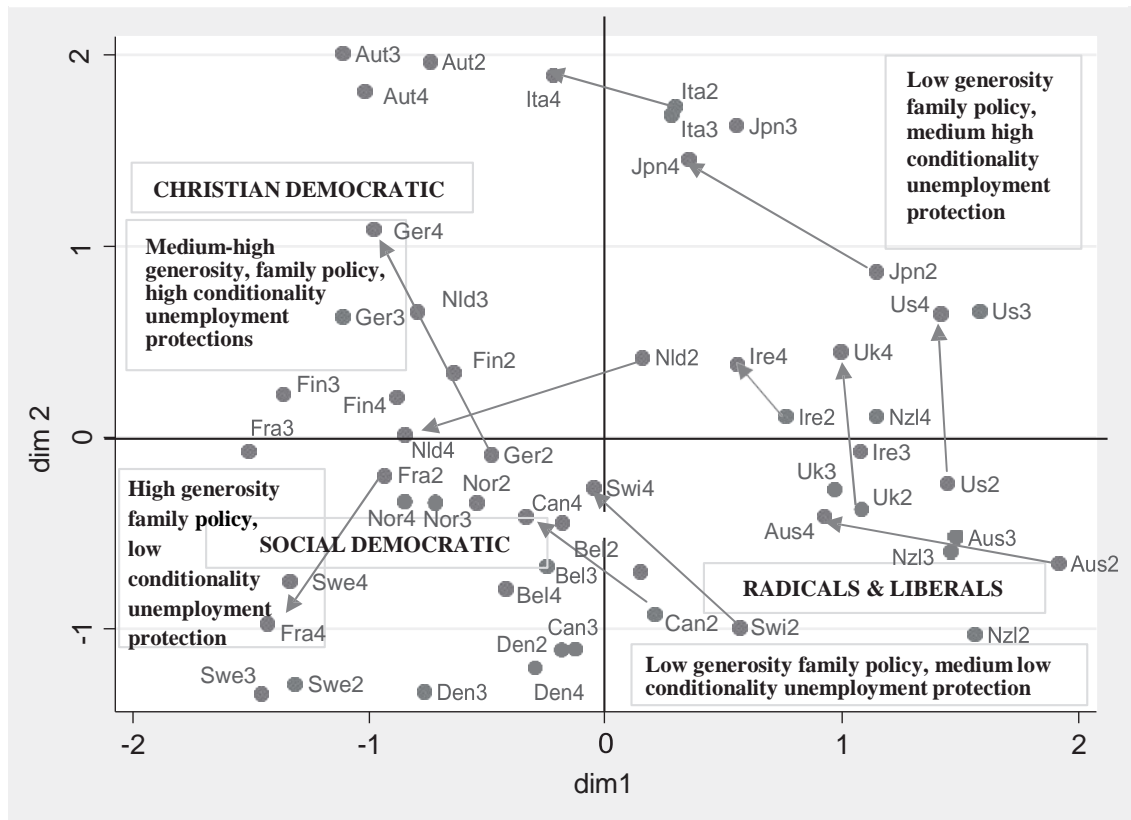

Source: Authors' elaboration.

Notes: Finland 2 represents the position of Finland in the 1980s, Finland 3 in the 1990s and Finland 4 in the 2000s and so forth for the other countries.

For country abbreviations, see figure 2 .

In theory, coverage, qualifying and waiting periods measure the degree of universalism of social transfer programmes, whereas replacement rates and duration capture the generosity of the cash transfer. Since we follow Esping-Andersen's measurement of decommodification for

compared to the models presented were negligible.

${ }^{4}$ Due to limited availability of indicators relating to social stratification for the time period included in our analysis we refrained from using them. Scruggs and Allan (2008) revisited Esping-Andersen's social stratification index only for two relatively short periods of time. Conceptually, Esping-Andersen (1990) also used the concept of welfare mix to classify countries without proposing a precise set of indicators (for an empirical measurement, see Powell and Barrientos [2004]). 
the average production worker (APW), our analysis is largely limited to the social protection of 'insiders', without taking into account lower levels of protection for 'outsiders' (cf. SeeleibKaiser et al. 2012). Theoretically, there are two ways to overcome this limitation, by using micro simulation data or micro panel data. However, there is no readily available dataset for the 18 OECD countries and the time period included in this analysis.

Taking up Lewis' (1992) criticism, whereby the care-welfare nexus constitutes an integral part of any welfare arrangement, Esping-Andersen (1999) included defamilialization into his static model and argued that the theory of the three worlds of welfare capitalism would still hold. Defamilialization captures the degree of familialism within a welfare state, measuring 'policies that lessen individuals' reliance on the family; that maximize individuals' command of economic resources independently of familial or conjugal reciprocities' (Esping-Andersen 1999: 45).

Figure 6

Multiple Correspondence Analysis family policy over three decades, 1980s, 1990s and 2000s (Model 3)

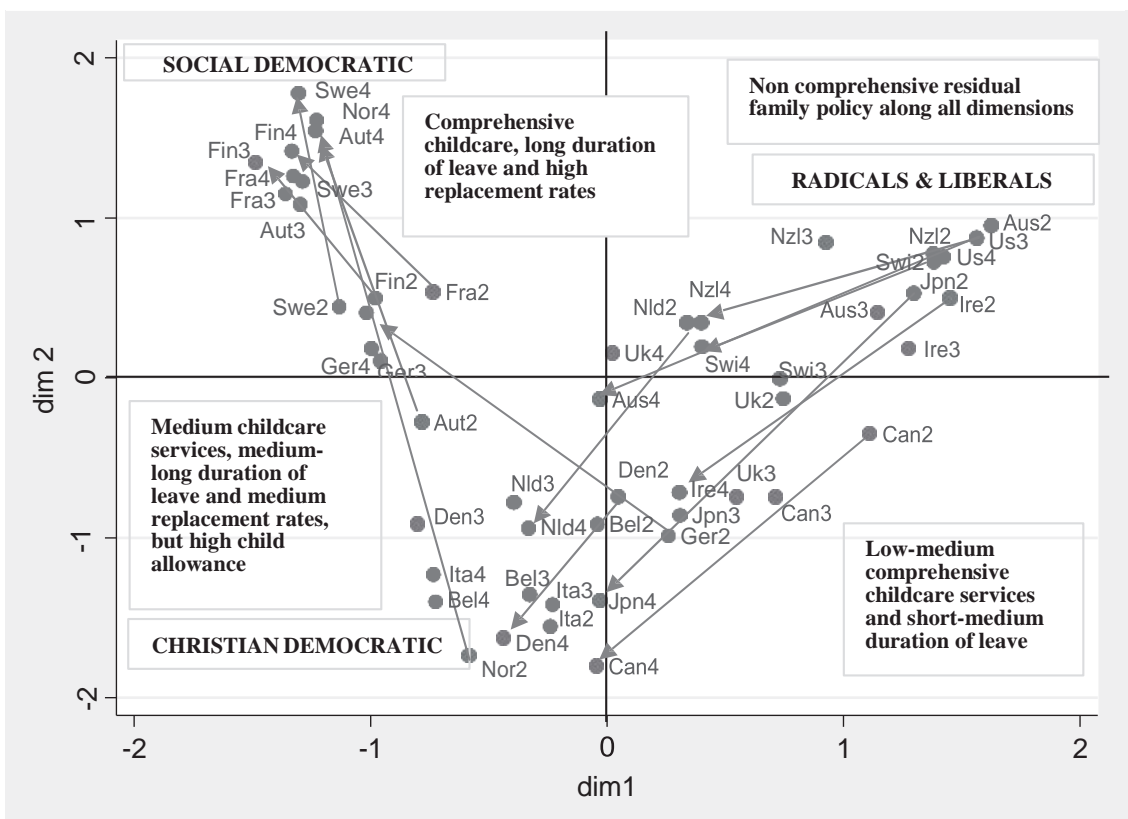

Source: Authors' elaboration.

Note: Finland 2 represents the position of Finland in the 1980s, Finland 3 in the 1990s and Finland

4 in the 2000s and so forth for the other countries.

For country abbreviations, see figure 2 .

However, despite the importance of path dependence it cannot be assumed that policies, including family policies, remain stable over long periods of time. Moreover, various scholars (e.g. Lewis and Campbell 2007; Fleckenstein and Seeleib-Kaiser 2011; Seeleib-Kaiser and Toivonen 2011) have argued that family policy has not only moved centre-stage in policy debates, but has undergone significant change in many countries, including those previously categorized by a strong male breadwinner model (Daly 2011). A shortcoming of these studies, however, is that they were either based on case studies or very small-n comparisons, which severely restricts their generalizability.

Following Lewis (2006) we have included the dimensions of benefits, services and time into our analysis. To capture the generosity of family transfer benefits we have considered a variable for the 
level of 'child allowances' into our model. The other two dimensions are much harder to measure. Due to the lack of internationally comparable longitudinal datasets for childcare provision, we have used a proxy measurement, derived from the OECD public social expenditure data for family services (OECD Social Expenditure Dataset [OECD 2010]). More specifically, our proxy is calculated as the expenditure for family services per child aged five and below (as a percentage of GDP). Despite using this proxy, we are unable to take into account important variables that measure the quality and generosity (including opening hours and out of pocket costs) of childcare arrangements. Lastly, we have relied on the updated 'Comparative Family Policy Database' (Gauthier 2011) for our variables relating to time, i.e. the various leave provisions (for a complete list of the variables included in our Model 2, see table 1). Due to limitations of data availability relating to childcare services we were unable to include the 1970s in our analysis and had to limit our study to the period from 1980 to 2008.

Figure 7

Multiple Correspondence Analysis unemployment protection over three decades, 1980s, 1990s and 2000s (Model 4)

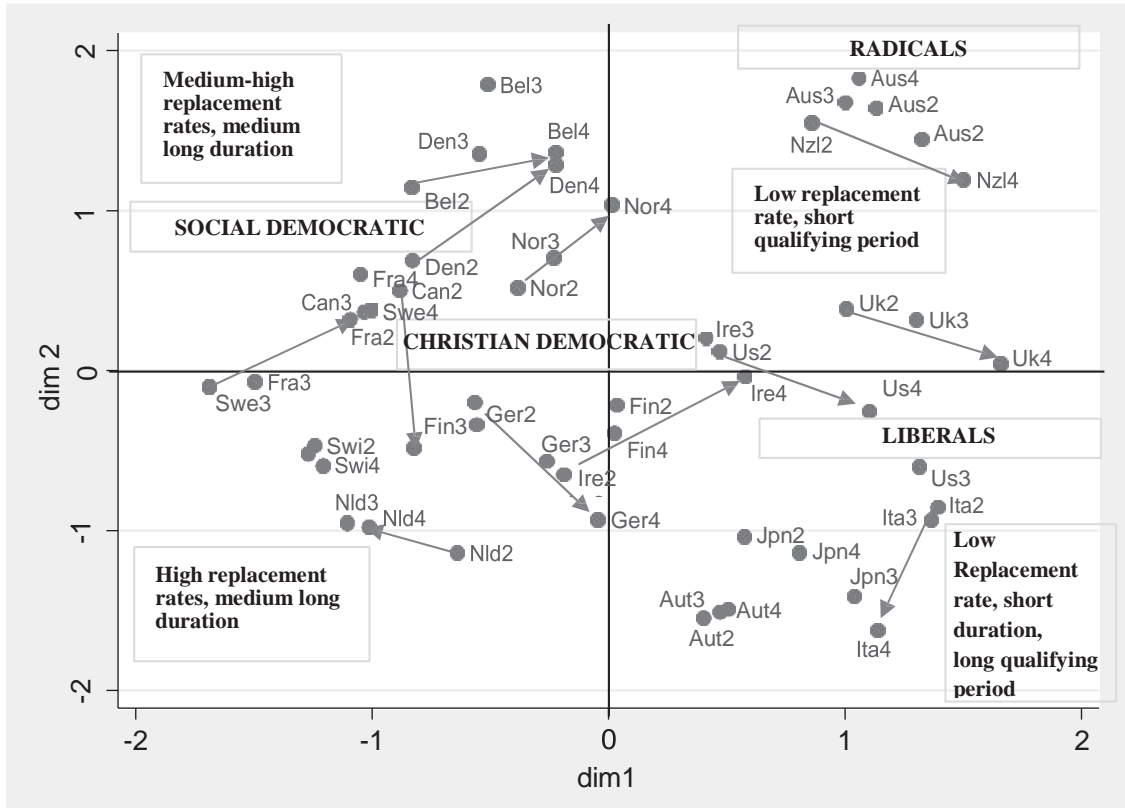

Source: Authors' elaboration

Note: Finland 2 represents the position of Finland in the 1980s, Finland 3 in the 1990 s and

Finland 4 in the 2000s and so forth for the other countries.

For country abbreviations, see figure 2 .

To summarize, in order to answer our substantive research question of welfare state regime continuity and change we estimate four different models:

1. A test of Esping-Andersen's welfare regime theory based on the decommodification concept.

2. An integrated analysis of unemployment protection and family policies; following the criticism that it might be more fruitful to analyze welfare state stability or change by scrutinizing single programmes or policy packages (see Seeleib-Kaiser 1995; Kasza 2002). 
We estimate two separate models for:

3. family policy; and

4. unemploymentprotection.

The data employed in our work are derived from the 'Welfare State Entitlement Dataset' (Scruggs 2004), which has been updated for the unemployment insurance variables for the time period from 2000 to 2008, the 'Comparative Family Policy Database' (Gauthier 2011) and the 'OECD Social Expenditure Dataset' (OECD 2010).

Table 1

Summary Multiple Correspondence Analysis analyses

\begin{tabular}{|c|c|c|c|c|}
\hline Policy Domains & $\begin{array}{l}\quad \text { Model } 1 \\
\text { Pension, } \\
\text { unemployment } \\
\text { protection, sickness }\end{array}$ & $\begin{array}{l}\text { Model } 2 \\
\text { Unemployment } \\
\text { protection, family policy }\end{array}$ & $\begin{array}{l}\text { Model } 3 \\
\text { Family policy }\end{array}$ & $\begin{array}{c}\text { Model } 4 \\
\text { Unemploymentprotection }\end{array}$ \\
\hline Indicators & $\begin{array}{l}\text { Unemployment (Scruggs 2004) } \\
\text { - } \text { Coverage } \\
\text { - Replacement rate (single APW) } \\
\text { - Replacement rate (family) } \\
\text { - } \text { Qualifying period } \\
\text { - } \text { Durating period } \\
\text { Sickness (Scruggs 2004) } \\
\text { - Coverage } \\
\text { - Replacement rate (single APW) } \\
\text { - Replacement rate (family) } \\
\text { - Qualifying period } \\
\text { - } \text { Daiting period } \\
\text { Pension (Scruggs 2004) } \\
\text { - Coverage } \\
\text { - Minimum/standard pension } \\
\text { single person/couple } \\
\text { replacement rate } \\
\text { - Qualifying period } \\
\text { Pension funding (employee } \\
\text { to employer ratio) }\end{array}$ & $\begin{array}{l}\text { Unemployment (Scruggs } 2004 \text { and } \\
\text { updating) } \\
\text { - Replacement rate (single APW) } \\
\text { - Replacement rate (family) } \\
\text { - Qualifying period } \\
\text { Family (Gauthier } 2011 \text { and updating) } \\
\text { - Total weeks leave } \\
\text { (maternity, parental, } \\
\text { childcare) } \\
\text { - Average replacement rate } \\
\text { (maternity, parental, } \\
\text { childcare) } \\
\text { - Allowance first child } \\
\text { - Expenditure for family services } \\
\text { per child aged five and below (as } \\
\text { a percentage of the GDP per } \\
\text { capita; OECD 2010) }\end{array}$ & $\begin{array}{l}\text { Family (Gauthier } 2011 \text { and updating) } \\
\text { - Total weeks leave } \\
\text { (maternity, parental, } \\
\text { childcare) } \\
\text { - Average replacement rate } \\
\text { (maternity, parental, } \\
\text { childcare) } \\
\text { - Allowance first child } \\
\text { - Expenditure for family services } \\
\text { per child aged five and below (as } \\
\text { a percentage of the GDP per } \\
\text { capita; OECD 2010) }\end{array}$ & $\begin{array}{l}\text { Unemployment (Scruggs } 2004 \text { and } \\
\text { updating) } \\
\text { - Replacement rate (single APW } \\
\text { - Replacement rate (family) } \\
\text { - Qualifying period } \\
\text { - Duration }\end{array}$ \\
\hline Dimension 1 & $35.2 \%$ & $48.70 \%$ & $75.85 \%$ & $46.24 \%$ \\
\hline Dimension 2 & $18.8 \%$ & $14.45 \%$ & $9.77 \%$ & $28.43 \%$ \\
\hline Observations & 300 & 459 & 510 & 470 \\
\hline
\end{tabular}

Source: Authors' elaboration.

\section{Discussion}

The first empirical model (see figures 2 and 3), employing a temporal approach to analyzing the concept of decommodification over three decades, addresses the research question of overall regime stability and change at a very high level of abstraction. The other three empirical models (see figures 4, 5, 6 and 7) address the question of stability and change within a more narrow and focused design of only considering unemployment protection and the generosity of family policy jointly and separately.

Assessing Esping-Andersen's decommodification classification with Multiple Correspondence Analysis

Taking a longitudinal approach for the period from 1971 to 1999, we analyzed the decommodification potential of 18 OECD countries using the measurement suggested by EspingAndersen (1990) based on coverage, replacement rates, qualifying and waiting periods as well as duration for unemployment, sickness and pension benefits (see table 1). Our Model 1 (see table 1) explains 54 per cent of the variance using these indicators. 
In figure 2 Norway, Denmark, Sweden and the Netherlands are located in the bottom left quadrant; these countries can be considered Social-Democratic welfare states, as they have a high level of universalism and generous cash transfers (for the interpretation of each space see figure A2*). On the left of the horizontal axis we find Austria, Germany and Belgium, which can be considered Christian-Democratic countries, as they display a medium degree of universalism and an intermediate level of generosity for cash transfers.

At the top of the vertical axis we find Japan, Canada, Italy, Switzerland, the USA, and the UK, which can be considered Liberal welfare states with a low degree of universalism and 'lean' cash transfers. This group is the most heterogeneous; however, Italy, Switzerland, Canada and Japan are clearly closer to the Christian-Democratic countries than the Anglo-Saxon Liberal countries. In qualitative research Italy has been classified as part of the Mediterranean regime (Leibfried 1992; Ferrera 1993; Bonoli 1997), due to its comparatively limited and dualistic social insurance system (see figure $\mathrm{A} 2 *$ ). Switzerland has been classified either as Liberal or as Christian-Democratic, as argued by Obinger (1998). The positioning of Switzerland among the Liberals does not exclude the presence of Christian-Democratic characteristics, i.e. the level of the replacement rate for standard pensioners. Canada has been traditionally classified as belonging to the Liberal cluster; however, Canada displays more generous replacement rates for unemployment and old age pensions than the USA (the differences between the US-American and the Canadian welfare states have been well documented by Myles [1998]). Japan has often been classified as a hybrid (i.e. Esping-Andersen 1997) and hence not surprisingly the MCA shows that Japan has an overall profile very similar to Liberal countries, however, with some features very close to those found in countries belonging to the Christian Democratic regime, e.g. the replacement rate for standard pensioners (see figure A2*).

To the right of the horizontal axis we find New Zealand and Australia, countries that have been characterized as Radical welfare states by Castles and Mitchell (1992). These countries have a system of reverse means-testing and thus can be considered as having a higher degree of universalism. Finally, France and Finland are somewhat hybrid. France is located between the Social-Democratic and the Christian-Democratic regimes and Finland is close to the Social-Democratic regime without being fully incorporated.

To summarize, the MCA model suggests the existence of four distinct worlds of welfare: the Social-Democratic welfare states (Norway, Denmark, Sweden and the Netherlands), the ChristianDemocratic welfare states (Austria, Germany and Belgium), the Liberal welfare states (Japan, Canada, Italy, Switzerland, the USA and the UK) and the Radical welfare states (Australia and New Zealand). This classification suggests six differences to Esping-Andersen's initial regime classification, the most important being that Australia and New Zealand belong to a separate Radical rather than to the Liberal world (confirming Castles and Mitchell 1992). Furthermore, whereas Italy and Switzerland tend to belong to the Liberal rather than the Christian- Democratic world (confirming Bambra 2006), Austria and Belgium seem to belong to the Christian-Democratic rather than to the Social-Democratic world, confirming Scruggs and Allan (2006).

\section{Assessing welfare regime stability over time}

From an empirical point of view Scruggs and Allan (2006) have argued that regime theory has been employed in a static fashion, as Esping-Andersen's regime types were based on an analysis of a 
historical snapshot at a certain point in time. Furthermore, a variety of scholars have suggested a transformation of the welfare state highlighting various degrees of 'retrenchment' and/or 'recalibration', whereas others have underlined welfare state 'resilience' (Clayton and Pontusson 1998; Jessop 1993; Pierson 1996, 2001; Starke 2006; Taylor-Gooby 2002). Following this debate we propose a dynamic approach to welfare regime theory; our analysis is based on average scores for three decades for each of the 18 OECD countries (see figure 3 ).

In contrast to the literature highlighting radical welfare state change our results show a remarkable stability of welfare regimes over time (see figure 3). Of the 18 OECD countries only Finland, Norway and the UK have moved substantially in the 1980s, compared to the 1970s. At the end of the 1970s, Finland and Norway shifted from the Liberal to the Social-Democratic world. These movements are not surprising, as it is generally acknowledged that Finland and Norway were SocialDemocratic latecomers that consolidated the welfare state in the 1980s (Kuhnle 2009). The UK has clearly moved towards the American prototype of welfare state Liberalism, without changing regime. This shift can be explained by the policies of the Thatcher era, which led to a significant reduction of replacement rates - a development not reversed by subsequent Labour governments (Toynbee and Walker 2005; Powell 2008). However, it has to be emphasized that the overall picture is one of stability.

Nevertheless, it is important to acknowledge that despite measuring overall stability major shifts may have taken place in countries that cannot be identified in our macro-comparative analysis for three reasons. First, due to the very high 'level of abstraction', only the most dramatic shifts can be captured through this kind of analysis. Second, the overall stability of welfare regimes might be partially driven by the continued impact of past pension policies. The scores used in the model reflect the generosity for current pensioners, who accrued their pension rights during the 'golden welfare state era'. For various reasons this group has been less affected by more recent pension reforms, compared to significant pension retrenchment for future pensioners in a number of OECD countries (Hinrichs 2000). Third, reforms in the various programmes might point in different directions and thereby cancel out the reforms in specific programmes.

Furthermore, taking into account the emergence of 'new' social risks (Bonoli 2005; Taylor-Gooby 2004) and the fact that reformed unemployment protection and family policies, unlike sickness and pension benefits, constitute a core element in recently highlighted activation and social investment strategies for future generations (Morel et al. 2012; Häusermann and Palier 2008); we theoretically could be witnesses of major policy changes that cannot be identified by Model 1.

\section{Assessing the evolution of unemployment protection and family policy}

In what follows we focus exclusively on unemployment protection and family policy. Our classification of 18 OECD countries in Model 2 (see figure 4) explains 63.15 per cent of the variance of the generosity of unemployment protection and family policy. Once again the spaces occupied by the various countries can be closely related to regime theory (for the interpretation of the spaces, see figure ${ }^{*}{ }^{*}$ ). In the bottom left quadrant we find Sweden, Denmark, Norway and France. These Nordic countries and France score highly on family policy generosity and the degree of universalism for the unemployed. Closely located to this Social-Democratic space are Switzerland, Belgium and Canada. Bambra (2006) as well as Scruggs and Allan (2006) have emphasized that Switzerland and Belgium 
share some of the characteristics of Social-Democratic countries, i.e. the generous replacement rate for family leaves. Also Canada is closer to the Social-Democratic than the Liberal space, due to its generosity of unemployment protection.

The top left quadrant is occupied by Finland, Germany and the Netherlands; these countries display quite generous family policy and have a medium-high degree of conditionality for unemployment protection. Although the distance of Austria and Italy to the core ChristianDemocratic countries seems to be far, they share many of their characteristics. Their distant position from the other Christian-Democratic countries is mainly explained by the long qualifying periods for unemployment insurance in the case of Austria and the short duration of unemployment protection in the case of Italy. Prima facie it might come as a surprise to find Finland and the Netherlands in the Christian-Democratic space. However, as is well known from the literature, the Netherlands traditionally has had a very strong-male breadwinner model and including that perspective could thus be considered a Christian-Democratic welfare state (cf. Lewis et al. 2008; Seeleib-Kaiser et al. 2008).

Finland is situated at the 'border' of the Christian-Democratic and Social- Democratic space. As shown in figures 5 and 6, Finland clearly belongs to the Social-Democratic universe with respect to family policy, whilst the institutional arrangements for unemployment protection remain close to the Christian-Democratic space. The space at the bottom right of figure 4 includes Australia, New Zealand, the UK, Ireland and the USA. In contrast to Model 1, the Radicals are very closely located to the Liberals. These countries are characterized by a low generosity of family policy and a medium degree of conditionality regarding unemployment protection. Conditionality is higher in the USA, the UK and Ireland, while New Zealand and Australia offer more universal access. The 'outlying' position of Japan between the Liberal and the Christian Democratic space clearly highlights its seeming 'uniqueness' (Takahashi 1998).

Analyzing the dynamics of family and labour market policy for each decade, the picture of regime stability weakens significantly (see figure 5 ).

With a very few exceptions, family policy (Model 3$)^{5}$ has undergone significant changes - (see figure 6) we are indeed witnesses of a revolution, although perhaps an incomplete one (EspingAndersen 2009). This whole process can be characterized as a 'socialization' of family policy, which in the past very often has been associated with Sweden. This 'socialization' encompasses a process towards family policies featuring comprehensive childcare services and long leave entitlements with high replacement rates (for the interpretation of the spaces, see figure A4*). Japan, New Zealand, Switzerland and Canada do not seem to follow the trend towards these services and Denmark and the Netherlands seem to move counter to the overall trend. This counterintuitive finding, especially as Denmark is often characterized as the country with the most generous family policy (cf. EspingAndersen 2009), can be explained by the fact that Gauthier's family dataset only includes data for the replacement rate of leave policies provided directly by the state without considering the contribution of employers, often arranged through collective bargaining agreements. Denmark and the

\footnotetext{
${ }^{5}$ Model 3 explains 85.63 per cent of the variance (see table 1 ).
} 
Netherlands have relatively high 'real' replacements rates, if occupational leave policies are included (Rostgaard 2010; Groenendijk and Keuzenkamp 2010).

Model $4^{6}$ (see figure 7) shows the historical development of unemployment protection from 1980 to 2008. According to this model the overwhelming majority of countries reduce the level of cash transfers for unemployment (for the interpretation of the spaces, see figure $A 5^{*}$ ), While some countries, such as Denmark, which is internationally known for its flexicurity approach (Madsen 2004), have reduced the level of conditionality, other countries, such as Germany and Italy, have significantly increased the conditionality of unemployment protection, leading to increased social protection dualism (Seeleib- Kaiser et al. 2012).

Considering the development of family and unemployment protection policy we seem to observe a 'dual transformation of the welfare state', as highlighted for the German case by Bleses and Seeleib-Kaiser (2004). Considering the starting points of the various countries the changes in family policy have indeed been remarkable and are grosso modo in line with many of the demands made by feminist scholars many decades ago (Sassoon 1987).

\section{Conclusion}

By using the same indicators as those employed by Esping-Andersen (1990) we can delineate four distinct worlds of welfare that are relatively stable over time: the Social-Democratic, ChristianDemocratic, Liberal and Radical worlds. Overall, we identify six differences compared to EspingAndersen's initial findings: Australia and New Zealand form a world of their own, confirming Castles and Mitchell (1992); Italy and Switzerland can be classified as Liberal rather than the ChristianDemocratic (confirming Bambra 2006), while Austria and Belgium belong to the Christian-Democratic rather than to the Social-Democratic world (confirming Scruggs and Allan 2006). However, it has to be highlighted that Esping-Andersen identified 'ideal-types as a necessary prelude to further theorization' (Powell and Barrientos 2011: 70); hence, the identified differences do not disprove the general validity of his regime framework and the real worlds of welfare should not be confused with ideal-types.

However, the integrated analysis of unemployment protection and family policies suggests clear limits of the regime approach. Our findings indicate three worlds of welfare capitalism and a rather large number of countries (one third of the total) that are very difficult to clearly classify (Austria, Italy, Japan, Belgium, Canada and Switzerland). Moreover, the picture of policy stability weakens. Once the two policy domains of family policy and unemployment protection are analyzed separately the concept of welfare regimes does not seem to hold, supporting those who have suggested that it might be more helpful to analyze the various welfare programmes or arrangements separately. Furthermore, we witness significant policy change over time, which can clearly be interpreted as transformative, especially with regard to family policies.

At the methodological level we were able to show that MCA can overcome some of the shortcomings of various other methods previously used in the literature, by employing a more

\footnotetext{
${ }^{6}$ Model 4 explains 74.68 per cent of the variance (see table 1 ).
} 
suitable treatment of variables with non-normal distributions and utilizing an innovative way to plot the evolution of countries over time. More specifically, MCA associates the position of each country with specific indicators by combining case and category plots. These plots allow a nuanced positioning of countries within a policy space and a more differentiated understanding of complex welfare state change and continuity.

Despite the substantive and methodological contributions, we did not address some important limitations identified in the comparative welfare regime literature, namely the focus on the average (production) worker (Emmenegger et al. 2012; Goodin et al. 1999), the existence of a certain level of benefit conditionality which is not captured by the concepts of decommodification and defamilialization, the recent introduction of workfare measures and the more widespread use of negative income tax in social policy. In this respect further analysis is required at the macrocomparative level (cf. Scruggs 2007; Kvist 2007).

To sum-up: welfare regime theory can function as a heuristic device to classify institutional arrangements of welfare states at a very general and abstract level during the past three decades within the OECD world. However, this finding does not rule out the occurrence of significant, or even transformative, policy shifts, as shown for the domains of family policy and unemployment protection. By using MCA we can overcome the idiosyncratic analyses of individual country case and small-n studies and identify generalizable trends without having to fully sacrifice the complexity and multidimensionality of institutional welfare arrangements and their development over time.

\section{Acknowledgements}

This work was supported by an ESRC grant (RES-239-25-0029) for the project: Integrating Macro and Micro Perspectives in Cross-National Comparison: Dynamic Policy Structures and Individual Outcomes. 


\section{References}

Arcanjo, M. (2006), Ideal (and Real) Types of Welfare State, Lisbon: CISEP.

Art, W. A. and Gelissen, J. (2002), Three Worlds of Welfare Capitalism or More? Journal of European Social Policy, 12: 137-58.

Art, W. A. and Gelissen, J. (2010), Models of the Welfare State. In F. C. Castles, et al. (eds), The Oxford Handbook of the Welfare State, Oxford: Oxford University Press.

Bambra, C. (2004), The Worlds of Welfare: Illusory or Gender Blind? Social Policy and Society, 3: 20111.

Bambra, C. (2005), Cash Versus Services, Journal of Social Policy, 34: 195-213.

Bambra, C. (2006), Decommodification and the Worlds of Welfare Revisited, Journal of European Social Policy, 16: 73-80.

Bambra, C. (2007), Defamilisation and Welfare State Regimes, International Journal of Social Welfare, 16: 326-38.

Bleses, P. and Seeleib-Kaiser, M. (2004), The Dual Transformation of the German Welfare State, Basingstoke and New York, NY: Palgrave.

Bonoli, G. (1997), Classifying Welfare States, Journal of European Social Policy, 26: 351-72.

Bonoli, G. (2005), The Politics of the New Social Policies, Policy \& Politics, 33: 431-9. Bonoli, G. (2007), Time Matters, Comparative Political Studies, 40: 495-520.

Bourdieu, P. (1979), La Distinction. Critique Sociale du Jugement, Paris: Éditions de Minuit.

Busemeyer, M. R. and Nikolai, R. (2010), Education. In F. C. Castles, et al. (eds), The Oxford Handbook of the Welfare State, Oxford: Oxford University Press.

Castles, F. C. and Mitchell, D. (1992), Identifying Welfare State Regimes, Governance: An International Journal of Policy and Administration, 5: 1-26.

Castles, F. G. and Obinger, H. (2008), World, Families, Regimes, West European Politics, 31: 321-44.

Clayton, R. and Pontusson, J. (1998), Welfare State Retrenchment Revisited, World Politics, 51: 6798.

Crompton, R. (2006), Employment and the Family, Cambridge: Cambridge University Press.

Daly, M. (2011), What Adult Worker Model? A Critical Look at Recent Social Policy Reform in Europe from a Gender and Family Perspective, Social Politics, 18: 1-23.

Emmenegger, P. et al. (2012), The Age of Dualization, New York, NY: Oxford University Press.

Esping-Andersen, G. (1990), The Three Worlds of Welfare Capitalism, Cambridge: Polity Press and Princeton, NJ: Princeton University Press.

Esping-Andersen, G. (1997), Hybrid or Unique?: the Japanese Welfare State Between Europe and America, Journal of European Social Policy, 7: 179-89.

Esping-Andersen, G. (1999), The Social Foundations of Postindustrial Economies, Oxford: Oxford University Press.

Esping-Andersen, G. (2009), The Incomplete Revolution, Cambridge: Polity Press.

Ferragina, E. and Seeleib-Kaiser, M. (2011), The Welfare Regime Debate: Past, Present, Futures? Policy \& Politics, 39: 583-611.

Ferrera, M. (1993), Modelli di Solidarietà, Bologna: II Mulino.

Ferrera, M. (1996), The 'Southern Model' of Welfare in Social Europe, Journal of European Social Policy, 6: 17-37.

Fleckenstein, T. and Seeleib-Kaiser, M. (2011), Business, skills and the welfare state: the political economy of employment-oriented family policy in Britain and Germany, Journal of European Social Policy, 21: 136-49.

Gal, J. (2004), Decommodification and Beyond, Journal of European Social Policy, 14: 55-69. 
Gallie, D. and Paugam, S. (2000), Welfare Regimes and the Experience of Unemployment in Europe, Oxford: Oxford University Press.

Gauthier, A. (2011), Comparative Family Policy Database.

Gilbert, N. (2008), A Mother's Work, New Haven, CT: Yale University Press.

Goodin, R. E. (2001), Work and Welfare: Towards a Post-Productivist Welfare Regime, British Journal of Political Science, 31: 13-39.

Goodin, R. et al. (1999), The Real Worlds of Welfare Capitalism, Cambridge: Cambridge University Press.

Goodman, R. and Peng, I. (1996), The East Asian Welfare State. In G. Esping- Andersen (ed.), Welfare States in Transition, London: Sage.

Gough, I. (2001), Social Assistance Regimes, Journal of European Social Policy, 11: 165-70.

Groenendijk, H. and Keuzenkamp, S. (2010), The Netherlands. In P. Moss (ed.), International Review of Leave Policies and Related Research 2010, London: Department for Business Innovation and Skills.

Häusermann, S. and Palier, B. (2008), The Politics of Employment Friendly Welfare Reforms in PostIndustrial Economies, Socio-Economic Review, 6: 559-86.

Hinrichs, K. (2000), Elephants on the Move. Patterns of Public Pension Reform in OECD Countries, European Review, 8: 353-78.

Huber, E. and Stephens, J. D. (2001), Development and Crisis of the Welfare State, Chicago, IL: The University of Chicago Press.

Hudson, J. and Kühner, S. (2009), Towards Productive Welfare? A Comparative Analysis of 23 OECD Countries, Journal of European Social Policy, 19: 34-46.

Hudson, J. and Kühner, S. (2012), Analyzing the Productive and Protective Dimension of Welfare: Looking Beyond the OECD, Social Policy \& Administration, 46: 35-60.

Jessop, B. (1993), Toward a Schumpeterian Workfare State? Studies in Political Economy, 40: 7-40.

Jollife, I. T. (2002), Principal Component Analysis, New York, NY: Springer.

Jones, C. (1993), The Pacific Challenge. In C. Jones (ed.), New Perspective of the Welfare State in Europe, London: Routledge.

Kangas, O. E. (1994), The Politics of Social Security. In T. Janoski and A. M. Hicks (eds), The Comparative Political Economy of the Welfare State, Cambridge: Cambridge University Press.

Kasza, G. J. (2002), The Illusion of Welfare Regimes, Journal of Social Policy, 31: 271-87.

Kautto, M. (2002), Investing in Services in West European Welfare States, Journal of European Social Policy, 12: 53-65.

Kittel, B. and Obinger, H. (2003), Political Parties, Institutions, and the Dynamics of Social Expenditure in Times of Austerity, Journal of European Public Policy, 10: 20-45.

Korpi, W. (1983), The Democratic Class Struggle, London: Routledge and Kegan Paul.

Korpi, W. and Palme, J. (1998), The Paradox of Redistribution and Strategies of Equality: Welfare State Institutions, American Sociological Review, 63: 661-87.

Kuhnle, S. (2009), The Nordic Model: Ambiguous, but Useful Concept. In H. Obinger and E. Rieger (eds), Wohlfahrtsstaatlichkeit in Entwickelten Demokratien, Frankfurt: Campus.

Kvist, J. (2007), Fuzzy Set Ideal Type Analysis, Journal of Business Research, 60: 474-81.

Kwon, H. J. (1997), Beyond European Welfare Regimes, Journal of Social Policy, 26: 467-84.

Kwon, H. J. (2005), Transforming the Developmental Welfare State in East Asia, Development and Change, 36: 477-97.

Le Roux, B. and Rouanet, H. (2010), Multiple Correspondence Analysis, London: Sage.

Lee, Y-J. and Ku, Y-W. (2007), East Asian Welfare Regimes: Testing the Hypothesis of the Developmental State, Social Policy \& Administration, 41: 197-212. 
Leibfried, S. (1992), Towards a European Welfare State? In F. Zsuza and J. E. Kolberg (eds), Social Policy in Changing Europe, Frankfurt: Campus.

Lewis, J. (1992), Gender and the Development of Welfare Regimes, Journal of European Social Policy, 2: 159-73.

Lewis, J. (1993), Women and Social Policies in Europe: Work, Family and the State, Cheltenham: Edward Elgar.

Lewis, J. (2006), Employment and Care: the Policy Problem, Gender Equality and the Issue of Choice, Journal of Comparative Policy Analysis, 8, 2: 103-14.

Lewis, J. and Campbell, M. (2007), Work/Family Balance Policies in the UK since 1997: A New Departure? Journal of Social Policy, 36: 365-81.

Lewis, J. et al. (2008), Patterns of paid and unpaid work in Western Europe: gender, commodification, preferences and the implications for policy, Social Politics, 15: 261-86.

Madsen, P. K. (2004), The Danish model of 'flexicurity', European Review of Labour, 10: 187-207.

Mahon, R. (2006), The OECD and the Work/Family Reconciliation Agenda. In J. Lewis (ed.), Children, Changing Families and Welfare States, Cheltenham: Edward Elgar.

Morel, N., Palier, B. and Palme, J. (2012), Toward a Social Investment Welfare State, Bristol: Policy Press.

Myles, J. (1998), How to Design a 'Liberal' Welfare State: a Comparison of Canada and the United States, Social Policy \& Administration, 32: 341-64.

Obinger, H. (1998), Politische Institutionen und Sozialpolitik in der Schweiz, Frankfurt: Peter Lang.

Obinger, H. and Wagschal, U. (1998), Drei Welten des Wohlfahrtsstaates? In S. Lessenich and I. Ostner (eds), Welten des Wohlfahrtskapitalismus. Der Sozialstaat in Vergleichender perspektive, Frankfurt: Campus.

Obinger, H. and Wagschal, U. (2001), Families of Nations and Public Policy, West European Politics, 24: 99-114.

Organisation for Economic Co-operation and Development (OECD) (2010), Social Expenditure Database (SOCX).

Pierson, P. (1994), Dismantling the Welfare State, Cambridge: Cambridge University Press.

Pierson, P. (1996), The New Politics of the Welfare State, World Politics, 48: 143-79.

Pierson, P. (2001), Coping with Permanent Austerity. In P. Pierson (ed.), The New Politics of the Welfare State, Oxford: Oxford University Press.

Pontusson, J. (1995), Explaining the Decline of European Social Democracy. The Role of Structural Economic Change, World Politics, 47: 495-533.

Powell, M. (2008), Modernising the Welfare State, Bristol: Policy Press.

Powell, M. and Barrientos, A. (2004), Welfare Regimes and the Welfare Mix, European Journal of Political Research, 43: 83-105.

Powell, M. and Barrientos, A. (2011), An Audit of the Welfare Modelling Business, Social Policy \& Administration, 45: 69-84.

Reibling, N. (2010), Healthcare Systems in Europe, Journal of European Social Policy, 20: 5-18.

Rostgaard, T. (2010), Denmark. In P. Moss (ed.), International Review of Leave Policies and Related Research 2010, London: Department for Business Innovation and Skills.

Rueda, D. (2007), Social Democracy Inside Out, Oxford: Oxford University Press.

Sabatier, P. A. (1988), An Advocacy Coalition Framework of Policy Change, Policy Sciences, 21: 12968.

Saint-Arnaud, S. and Bernard, P. (2003), Convergence or Resilience? Current Sociology, 51: 499-527.

Sassoon, A. S. (1987), Women and the State, London: Hutchinson.

Schröder, M. (2009), Integrating Welfare and Production Typologies, Journal of Social Policy, 38: 1943. 
Scruggs, L. (2004), Welfare State Entitlements Data Set: A Comparative Institutional Analysis of Eighteen Welfare States, Version 1.1.

Scruggs, L. (2007), Welfare State Generosity across Space and Time. In J. Clasen and N. Siegel (eds), Investigating Welfare State Change, Cheltenham: Edward Elgar.

Scruggs, L. A. and Allan, J. P. (2006), Welfare State Decommodification in 18 OECD Countries, Journal of European Social Policy, 16: 55-72.

Scruggs, L. A. and Allan, J. P. (2008), Social Stratification and Welfare Regimes for the Twenty-first Century, World Politics, 60: 642-64.

Seeleib-Kaiser, M. (1995), The Development of Social Assistance and Unemployment Insurance in Germany and Japan, Social Policy \& Administration, 29: 269-93.

Seeleib-Kaiser, M. (2002), Neubeginn oder Ende der Sozialdemokratie? Politische Vierteljahresschrift, 43: 478-96.

Seeleib-Kaiser, M. et al. (2008), Party Politics and Social Welfare, Cheltenham: Edward Elgar.

Seeleib-Kaiser, M., Saunders, A. and Naczyk, M. (2012), Shifting the Public-Private Mix: A New Dualization of Welfare? In P. Emmenegger et al. (eds), The Age of Dualization, Oxford: Oxford University Press, pp. 151-75.

Seeleib-Kaiser, M. and Toivonen, T. (2011), Between Reforms and Birth Rates: Germany, Japan, and Family Policy Discourse, Social Politics, 18: 1-30.

Shalev, M. (1996), Introduction. In M. Shalev (ed.), The Privatization of Social Policy? London: Macmillan Press Ltd.

Shalev, M. (2007), Limits and Alternatives to Multiple Regression in Comparative Research, Comparative Social Research, 24: 261-308.

Soede, A. et al. (2004), Unequal Welfare States, The Hague: SCPO.

Starke, P. (2006), The Politics of the Welfare State Retrenchment: a Literature Review, Social Policy \& Administration, 40: 104-20.

Stephens, J. D. (1979), The Transition from Capitalism to Socialism, London: Macmillan.

Takahashi, M. (1998), The Emergence of Welfare Society in Japan, Aldershot: Ashgate.

Taylor-Gooby, P. (2002), The Silver Age of the Welfare State Perspectives on Resilience, Journal of Social Policy, 31: 597-621.

Taylor-Gooby, P. (2004), New Risks, New Welfare, Oxford: Oxford University Press.

Toynbee, P. and Walker, D. (2005), Better or Worse? Has Labour Delivered? London: Bloomsbury.

Vis, B. (2007), States of Welfare or States of Workfare? Policy \& Politics, 35: 105-22.

Vrooman, J. C. (2009), Rules of Relief, The Hague: SCPO.

Weber, M. (1904 [1949]), On the Methodology of the Social Sciences, Glencoe, IL: The Free Press.

Wendt, C. (2009), Mapping European Healthcare System, Journal of European Social Policy, 19: 43245.

Wendt, C., Mischke, M. and Pfeifer, M. (2011), Welfare States and Public Opinion, Cheltenham: Edward Elgar.

Wildeboer Shut, J. M., Vrooman, C. and De Beer, P. T. (2001), On Worlds of Welfare, The Hague: SCPO. 


\section{Appendix Figures}

Figure 1A. Unemployment Benefit Waiting Period

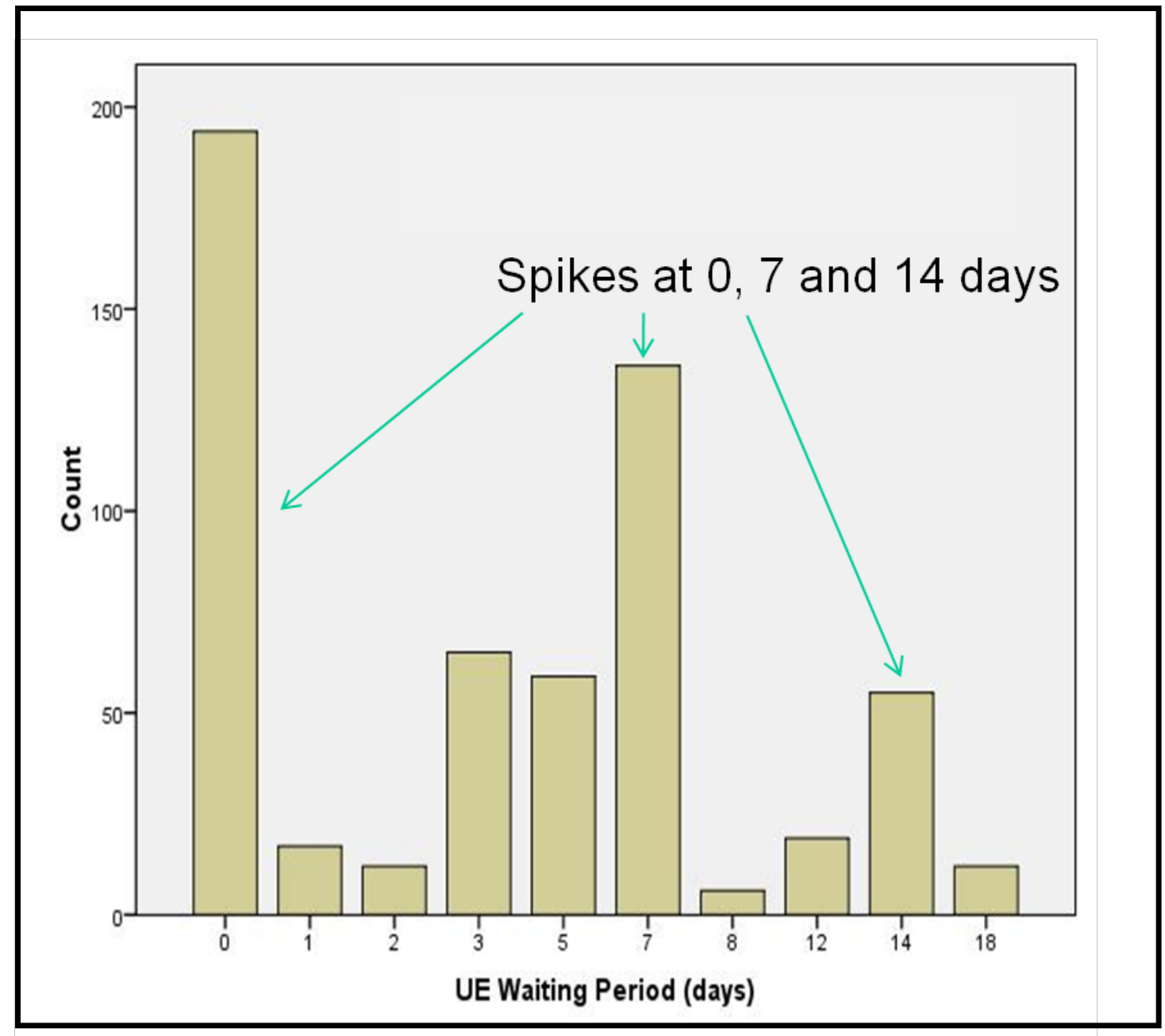

Source: author's elaboration after Scruggs (2004). 
Figure 2A. Category Plot: Interpretation MCA Decommodification 1971-1999 (Model 1)

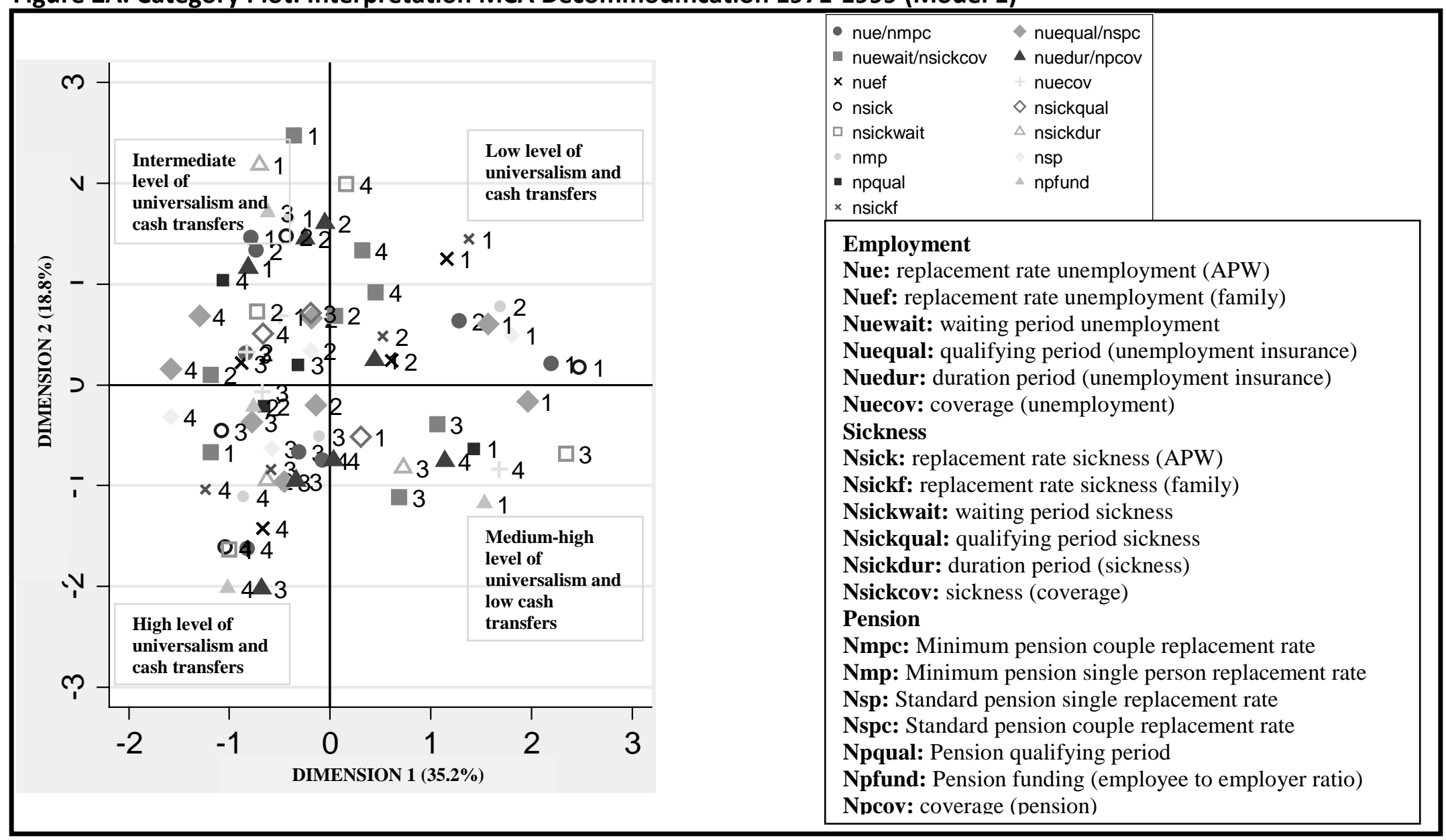

Note: $1=$ Lowest quartile; $4=$ top quartile.

Source: Authors' elaboration. 
Figure 3A. Category plot: Interpretation MCA Unemployment Protection and Family Policy 1980-2008 (Model 2)

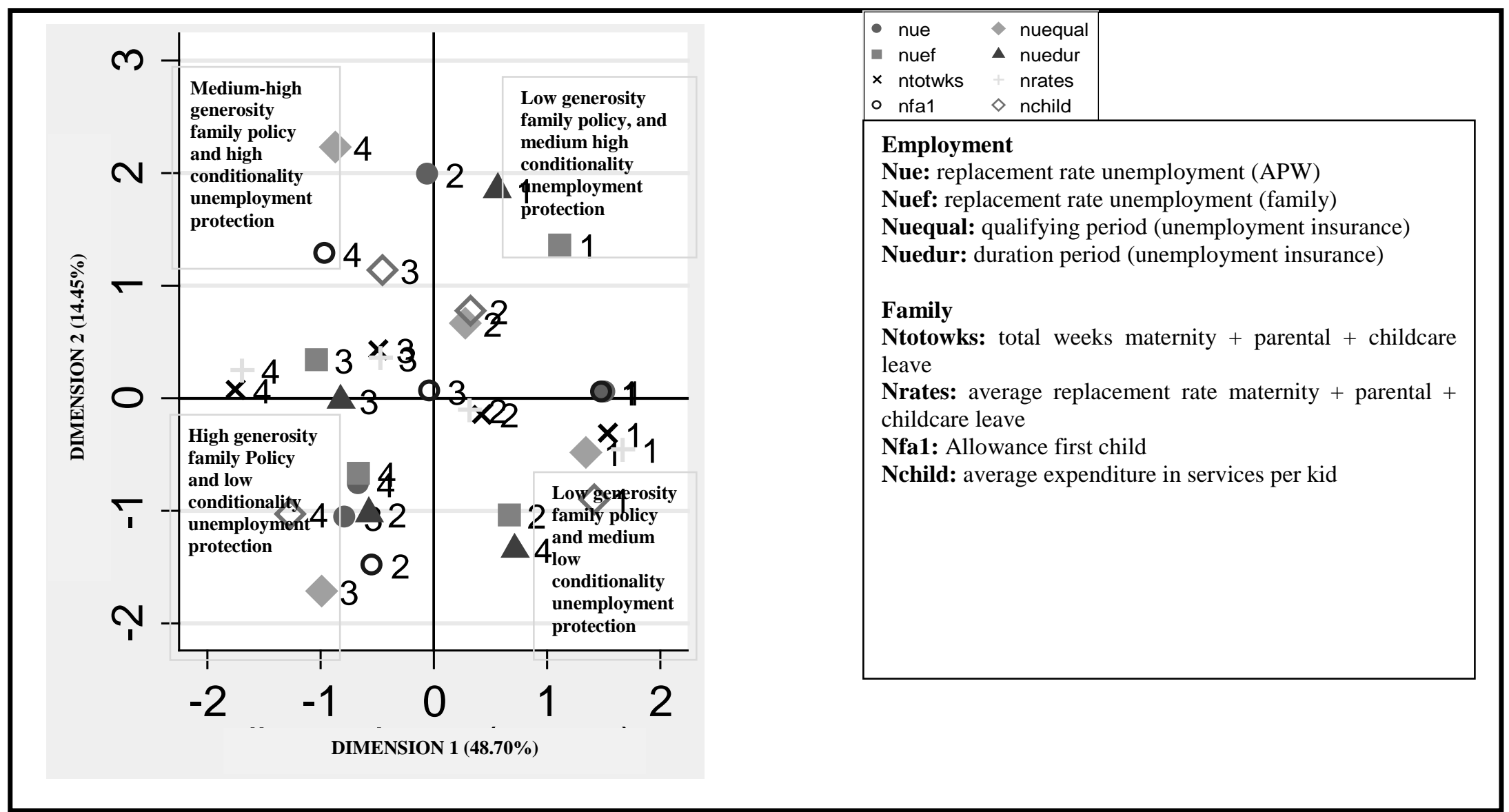

Note: $1=$ Lowest quartile; $4=$ top quartile.

Source: Authors' elaboration. 
Figure 4A. Category Plot: Interpretation MCA Family Policy 1980s, 1990s, 2000s (Model 3)

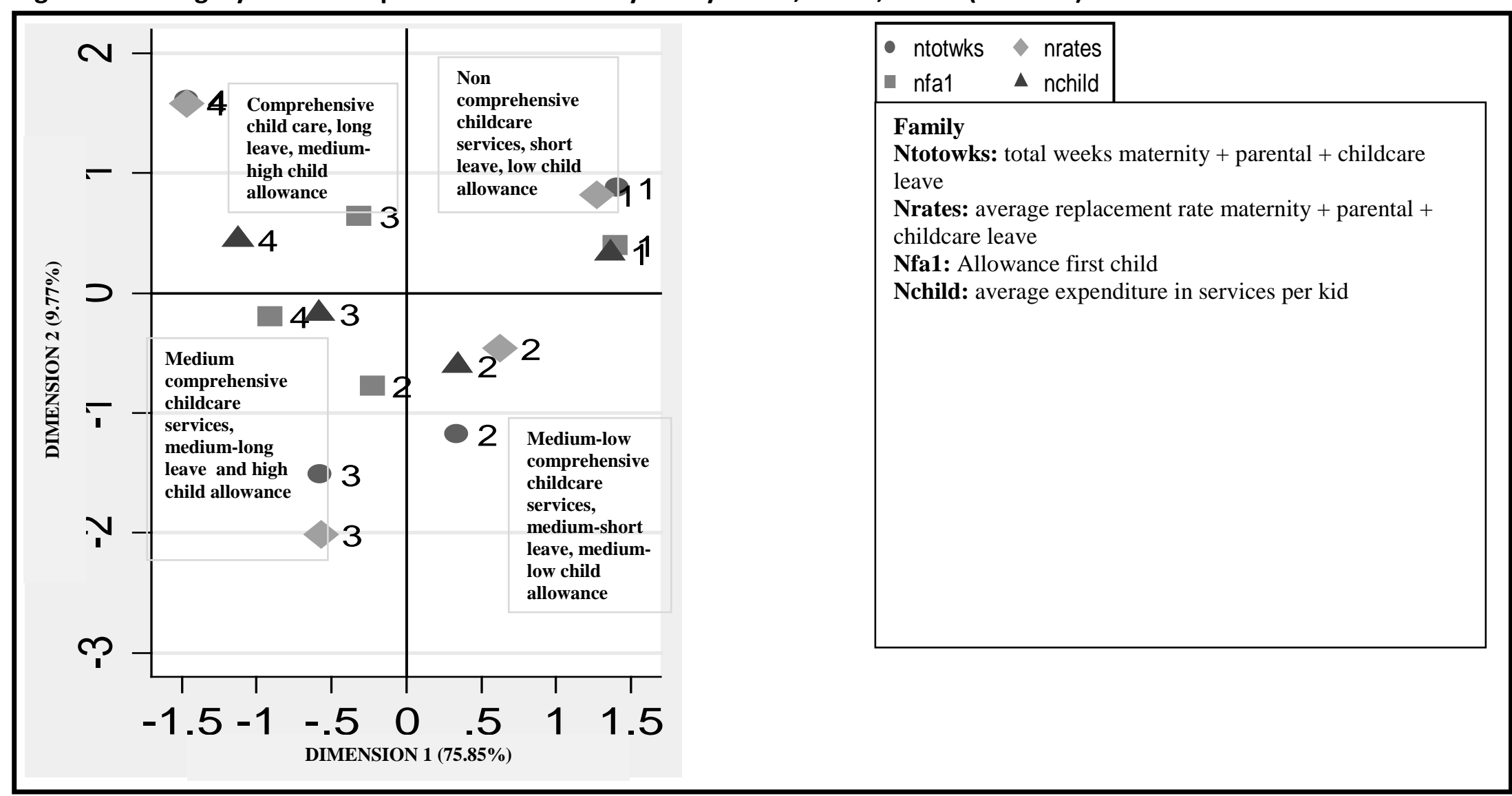

Note: $1=$ Lowest quartile; $4=$ top quartile.

Source: Authors' elaboration. 
Figure 5A. Category Plot: Interpretation MCA Unemployment Protection 1980s, 1990s, 2000s (Model 4)

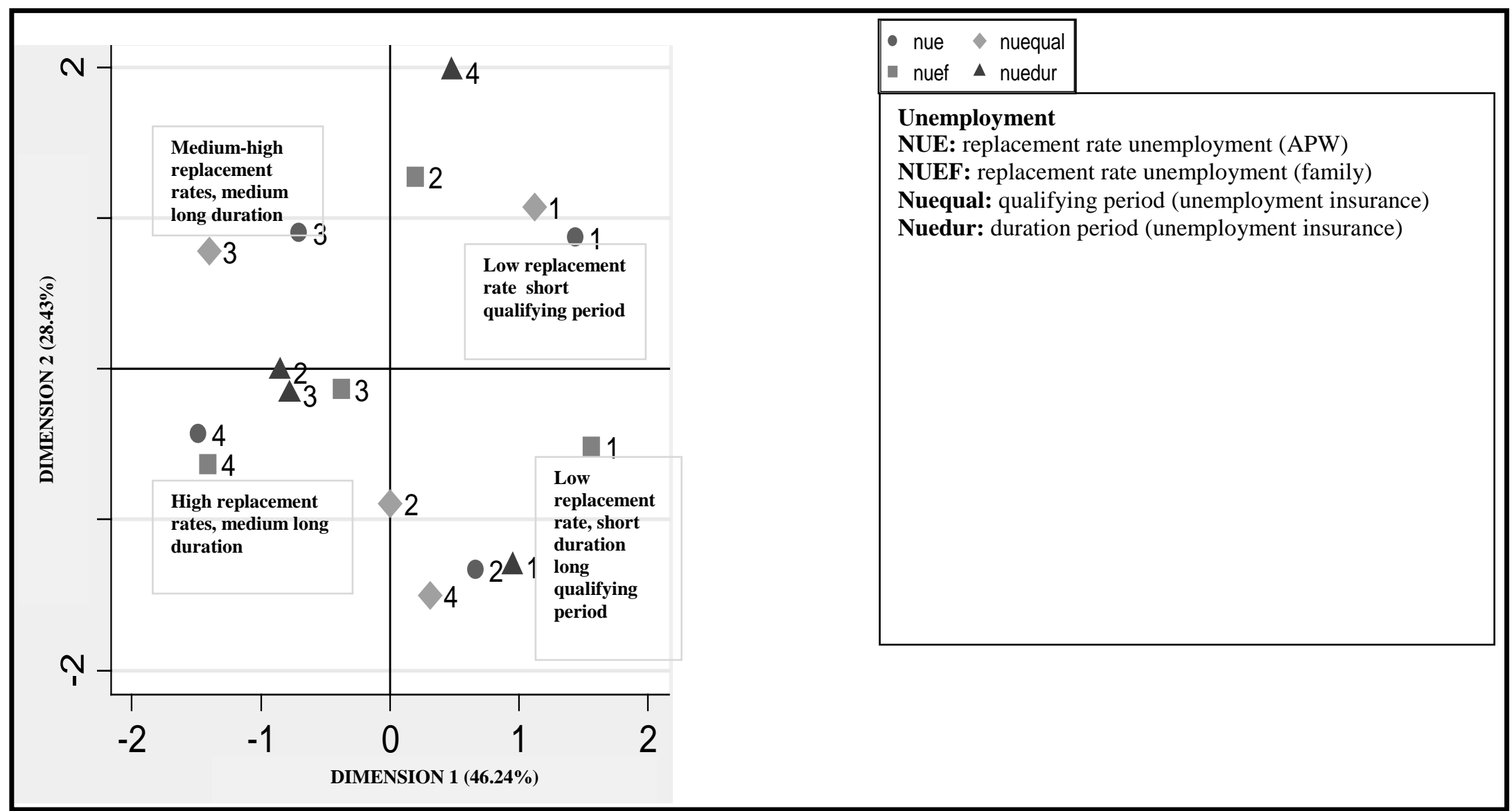

Note: $1=$ Lowest quartile; $4=$ top quartile.

Source: Authors' elaboration. 